\title{
Spatial reversal learning in the lizard Coleonyx variegatus
}

\author{
PATRICIA M. KIRKISH, JAMES L. FOBES, and ANN M. RICHARDSON \\ California State University, Los Angeles, California 90032
}

Banded geckos (Coleonyx variegatus) were trained, at the rate of five daily trials, on eight intradimensional spatial shifts to a criterion of $80 \%$ correct per reversal. In contrast to several previously reported failures to obtain reversal learning, Coleonyx demonstrated significant improvement on both errors and trials to criterion. Their reversal performance compares favorably with that of birds and mammals and a common index of reversal ability, the mean total error, did not differentiate between taxa.

While numerous species of birds and mammals have consistently demonstrated progressive improvement on spatial reversals (Warren, 1965, 1973), the data are conflicting for fish and reptiles. It was only after frequent failures (Behrend, Domesick, \& Bitterman, 1965; Bitterman, 1965a, 1965b; Bitterman, Wodinsky, \& Candland, 1958) that fish were reported to display improvement on such tasks (Mackintosh \& Cauty, 1971; Setterington \& Bishop, 1967; see also Squier, 1969). Since some of these successful investigations were with species previously reported not to demonstrate improvement, it now seems likely that these contrasting results with reversal learning (RL) performance represent differences due to procedural variations rather than due to functional differences between adjacent taxa.

A somewhat similar state of contradiction exists within the class reptilia in that while crocodilia (caiman, alligator, and crocodile) were reported to improve between reversals (Gossette \& Hombach, 1969; R. S. Williams, 1968), data for chelonia (turtle and terrapin) and squamata (lizard) are difficult to interpret. No improvement was initially reported for turtles tested by a correction procedure with both fixed number of trials and criterion methods (Kirk \& Bitterman, 1963). Eventually, however, this species was reported to improve when tested with guidance and a substantially greater fixed number of trials per reversal (Holmes \& Bitterman, 1966). The other chelonia, terrapin, were tested by a procedure that was inelegant to the point of eliminating any conclusion about their reversal ability (Seidman, 1949).

Two families of squamata have been tested for spatial reversal and several species of iguanidae (desert iguana and american chameleon) have been reported to demonstrate improvement (Norton, Peterson, \& Richardson, Note 1; Richardson, Garzanit, \& Albano,

The present addresses for the first and second authors are Department of Psychology, University of Arizona, Tucson, Arizona 85724, and Division of Biology, California Institute of Technology, Pasadena, California 91126, respectively.
Note 2). However, Gekkonidae (geckos) have been reported to show no improvement when tested with either a fixed number of trials (20) or a criterion (17/20) procedure (Baird, 1970; Baird \& Vance, Note 3). These failures to obtain spatial reversal improvement with Coleonyx variegatus are striking. In addition to the contrast in performance compared with other reptiles, geckos' successful acquisition of presumably more difficult tasks such as brightness and pattern discriminations (Baird, 1970) is difficult to reconcile. To avoid the confusion that ensued from acceptance of negative results with fish and other reptiles and the assertion that RL ability indicated functional differences (Bitterman, 1965a, 1965b, 1975), the present investigation was undertaken in the attempt to demonstrate spatial RL in geckos.

\section{METHOD}

\section{Subjects}

Subjects were three male and two female adult western banded geckos (Coleonyx variegatus) with an average snout-vent length of $6.5 \mathrm{~cm}$. They were communally housed in a glass terrarium $(46 \times 61 \times 91 \mathrm{~cm})$ furnished with flat rocks, wooden stumps, and hollow bamboo tubes on $27^{\circ} \mathrm{C}$ sand. The lizards were gentled by $20 \mathrm{~min}$ of daily handling for 2 weeks prior to beginning the study.

\section{Apparatus}

Spatial reversal training was conducted in a $Y$ maze (30-deg radials) featuring a $27^{\circ} \mathrm{C}$ substrate. Both choice arms led to identical darkened goalboxes with $31^{\circ} \mathrm{C}$ substrates. While a hinged door allowed ready access to the goalbox on the correct side $(\mathrm{S}+)$, entrance to the goal on the incorrect side $\left(\mathrm{S}_{-}\right)$was precluded by affixing the door in a closed position.

\section{Procedure}

Data were collected with these nocturnal subjects tested during the light phase of their daily cycle. While this may initially appear counterintuitive, superior learning performance has been reported for this species tested under such conditions (Baird, 1970), which may be due to a darkened goal having enhanced incentive value under such circumstances. A spatial choice was scored as the subjects' rear legs entered the left or right maze arm. While only the initial radial choice was subsequently analyzed, a correction procedure was employed in that retracing was permitted after selection of the $\mathrm{S}-$ maze 
arm. If retracing was successful and the lizard found its way into the correct radial and goalbox, it was allowed to remain in the box for $2 \mathrm{~min}$, as was the case subsequent to an initially correct choice. If the lizard did not retrace, it was removed $2 \mathrm{~min}$ after having crossed into the $\mathrm{S}-$ alley arm. After each trial the maze was cleaned to reduce the possibility of chemical cue contribution.

Subjects were tested daily for five trials with an average intertrial interval of $7 \mathrm{~min}$. Pretraining consisted of 60 trials with both goals accessible, during which individual spatial preferences were noted, and in the following acquisition phase individual nonpreferred sides were used as the S+. Subjects were trained to a criterion of $80 \%$ correct $(16 / 20)$. Upon reaching criterion in the acquisition phase (Reversal ${ }_{0}$ ), subjects were tested with the same criterion on eight spatial reversals that featured an intradimensional spatial shift of the $S+$ and $\mathrm{S}$ - between reversals.

\section{RESULTS}

Data consisting of errors and trials to criterion across acquisition and reversals were separately analyzed by repeated-measures analyses of variance. Both errors to criterion $[F(8,32)=3.12, \mathrm{p}<.025]$ and trials to criterion $[F(8,32)=2.67, \quad \mathrm{p}<.025] \quad$ significantly differed and are depicted in Figure 1.

Post hoc analyses of these effects by Duncan multiple range tests $(\mathrm{p}<.05)$ indicated: $(1)$ improvement across reversals on both errors and trials to criterion (the number of errors and trials was greater on the first than on the sixth, seventh, or eighth reversal), and (2) the functions relating reversals to trials and errors to criterion were linear with a negative slope (Reversals 2 , 3 , and 4 did not significantly differ in the number of errors or trials). The mean cumulative error for the eight reversals was 122 , and the reversal index scores (Rajalakshmi \& Jeeves, 1965) were .84 for errors and .75 for trials to criterion.

\section{DISCUSSION}

The present study clearly indicates improvement by geckos on intradimensional spatial shift, an ability not previously demonstrated possibly due to insufficient testing (fewer

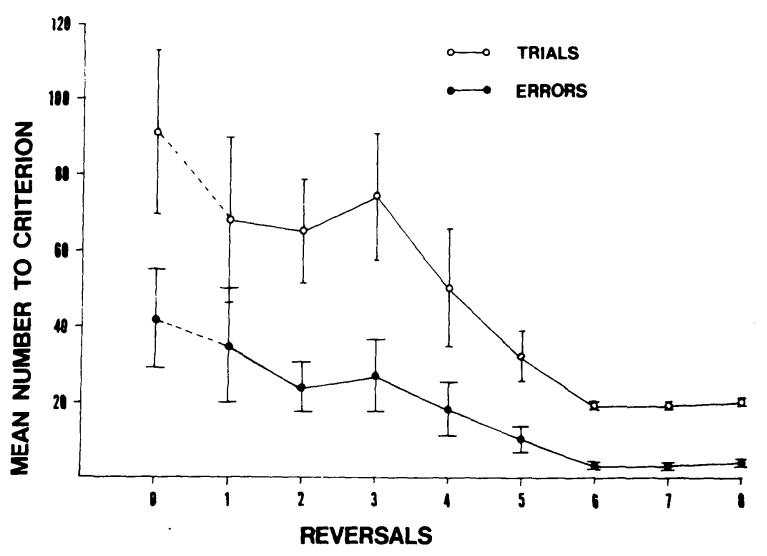

Figure 1. Average number of trials and errors to criterion with 1 standard deviation around the mean.
Table 1

Average Total Errors Across the Initial Eight Reversals

\begin{tabular}{lrl}
\hline \multicolumn{1}{c}{ Taxa } & $\begin{array}{c}\text { Mean Total } \\
\text { Error }\end{array}$ & \multicolumn{1}{c}{ Source } \\
\hline $\begin{array}{l}\text { Aves } \\
\text { chicken }\end{array}$ & 345 & Gossette, 1969c \\
chukar & 106 & Gossette and Hood, 1967 \\
dove & 266 & Gossette and Hood, 1967 \\
guinea fowl & 367 & Gossette, 1969c \\
magpie & 88 & Gossette, 1969c \\
myna & 193 & Gossette and Hood, 1967 \\
pigeon & 122 & Gossette, 1969c \\
trumpeter & 654 & Gossette, 1969c \\
Mammalia & & \\
bat & 134 & Ellins and Masterton, 1971 \\
cacomistle & 52 & Gossette et al., 1968 \\
capuchin monkey & 34 & Gossette, 1970a \\
coati-mundi & 125 & Gossette et al., 1968 \\
gibbon & 82 & Gossette, 1970a \\
kinkajou & 130 & Gossette et al., 1968 \\
mouse & 56 & Elias, 1970 \\
owl monkey & 101 & Gossette, 1970a \\
raccoon & 110 & Gossette et al., 1968 \\
rat & 117 & Mackintosh and Cauty, 1971 \\
skunk & 128 & Gossette et al., 1968 \\
squirrel monkey & 175 & Gossette, 1970a \\
Osteichthyes & & \\
goldfish & 152 & Mackintosh and Cauty, 1971 \\
Reptilia & & \\
American chameleon & 104 & Norton et al., Note 1 \\
gecko & 122 & Present investigation \\
\hline
\end{tabular}

Note-Values estimated from published figures.

reversals) and inappropriate statistical analysis (Baird, 1970; Baird \& Vance, Note 3). An additional factor that may have resulted in the present success is that of methodology. RL performance has been reported to be a function of: (1) schedule of reinforcement, deprivation level, and incentive magnitude (Gossette, 1969b; Kendler \& Lachman, 1958; Levine, 1974), (2) intertrial interval (Alpern \& Marriott, 1972; North, 1950; B. A. Williams, 1971), (3) number of trials per reversal (Holmes \& Bitterman, 1966; Pubols, 1962), (4) response criteria (Gossette, 1969a), (5) correction or noncorrection training (Gossette, 1969a; Miller, Hansen, \& Thomas, 1972), and (6) distance between manipulanda, as well as limited or unlimited correction (Setterington \& Bishop, 1967).

In order to assess geckos' performance, it was compared with that of other reptiles, fish, birds, and mammals. Comparisons were made by a method advocated by Gossette (1970a, 1970b) that uses a measure consisting of the average total number of errors across a constant number of reversals. Bearing in mind the limitations of contrasting studies with differing procedures and criteria, on the basis of this measure (across the eight reversals), geckos' performance was inferior to that of American chameleons (Norton et al., Note 1) and superior to that of goldfish (Mackintosh \& Cauty, 1971). Contrasted with avians, geckos were comparable to pigeons (Gossette, 1969c) and superior to chickens, doves, guinea fowl, mynas, and trumpeters (Gossette, 1969c; Gossette \& Hood, 1967). Performance comparisons with mammals led to the most striking conclusion: Geckos were comparable with coati-mundi, kinkajou, and skunks (Gossette, Kraus, \& Speiss, 1968) and were superior to bats and squirrel monkeys (Ellins \& Masterton, 1971; Gossette, $1970 \mathrm{a})$. To determine the predictive value of $R L$ in general, and of this apparent aberrant ability of geckos in particular, we computed where possible the average total number of errors across the first eight spatial reversals, as depicted in Table 1. 
No systemic relationship between this RL measure and taxonomic class was supported by a Kruskal-Wallis test, which failed to indicate a significant difference (fish were not included in the analysis). Thus, not only can geckos learn spatial reversals, but their performance is at least comparable with a variety of species.

\section{REFERENCE NOTES}

1. Norton, G., Peterson, E., \& Richardson, A. Serial reversal learning and orienting responses in the lizard Anolis carolinensis. Paper presented at the meeting of the Western Psychological Association, Los Angeles, April 1976.

2. Richardson, A. M., Garzanit, R., \& Albano, J. Habit reversal in the desert iguana. Paper presented at the meeting of the Western Psychological Association, Los Angeles, April 1970.

3. Baird, P., \& Vance, V. Brightness and pattern discrimination in the banded gecko, Coleonyx variegatus. Paper presented at the meeting of the Animal Behavior Society, Reno, May 1971.

\section{REFERENCES}

AlPern, H. P., \& MARRIott, J. G. A direct measure of short-term memory in mice utilizing a successive reversal learning set. Behavioral Biology, 1972, 7, 723-732.

BAIRD, P. A. Temperature-dependent brightness discrimination, pattern discrimination, and reversal learning in the banded gecko, Coleonyx variegatus. Unpublished masters thesis, California State University, Los Angeles, 1970.

Behrend, E. R., Domesick, V. B., \& Bitterman, M. E. Habit reversal in the fish. Journal of Comparative and Physiological Psychology, 1965, 60, 407-411.

Bitterman, M. E. The evolution of intelligence. Scientific American, 1965, 212, 92-100. (a)

Bitterman, M. E. Phyletic differences in learning. American Psychologist, 1965, 2, 396-409. (b)

Bitterman, M. E. The comparative analysis of learning: Are the laws of learning the same in all animals? Science, 1975, 188, 699-709.

Bitterman, M. E., Wodinsky, J., \& Candland, D. K. Some comparative psychology. American Journal of Psychology, 1958, 71, 94-110.

Elias, M. R. Differences in reversal learning between two inbred mouse strains. Psychonomic Science, 1970, 20, 179-180.

Ellins, S. R., \& Masterton, F. A. Successive spatial discrimination reversals in the bat. Psychonomic Science, 1971, 25, 265-266.

GoSSETTE, R. L. Magnitude of negative transfer of myna birds on a spatial SDR task as a function of stringency of reversal criterion. Perceptual and Motor Skills, 1969, 29, 621-622. (a)

GossetTE, R. L. Role of motivational and incentive levels in the control of successive discrimination reversal (SDR) performance in comparative analysis. Perceptual and Motor Skills, 1969, 28, 283-292. (b)

GosSETTE, R. L. Variation in magnitude of negative transfer on successive discrimination reversal (SDR) tasks across species. Perceptual and Motor Skills, 1969, 29, 803-811. (c)

Gossette, R. L. Comparisons of SDR performance of gibbons and three species of new world monkeys on a spatial task. Psychonomic Science, 1970, 19, 301-303. (a)

Gossette, R. L. Note on the calibration of inter-species successive discrimination reversal (SDR) performance differences: Qualitative vs quantitative scaling. Perceptual and Motor Skills, 1970, 31, 95-104. (b)
Gossette, R. L., \& Номвасн, A. Successive discrimination reversal (SDR) performance of american alligators and american crocodiles on a spatial task. Perceptual and Motor Skills, 1969, 28, 63-67.

Gossette, R. L., \& Hood, P. Successive discrimination reversal (SDR) performances of chukars, ringneck doves and greater hill mynas as a function of correction as opposed to non-correction procedures. Psychonomic Science, 1967, 8, 361-362.

Gossette, R. L., Kraus, G., \& Speiss, J. Comparison of successive discrimination reversal (SDR) performances of seven mammalian species on a spatial task. Psychonomic Science, 1968, 12, 193-194.

Holmes, P. A., \& Bitterman, M. E. Spatial and visual habit reversal in the turtle. Journal of Comparative and Physiological Psychology, 1966, 62, 328-331.

KENDLER, H. H., \& LACHMAN, R. Habit reversal as a function of schedule of reinforcement and drive strength. Journal of Experimental Psychology, 1958, 55, 584-591.

KirK, K. L., \& Bitterman, M. E. Habit reversal in the turtle. Quarterly Journal of Experimental Psychology, 1963, 15, 52-57.

LEVINE, B. A. Effects of drive and incentive magnitude on serial discrimination reversal learning in pigeons and chickens. Journal of Comparative and Physiological Psychology, 1974, 86, 730-735.

MaCkintosh, N. J., \& CAUTY, A. Spatial reversal learning in rats, pigeons, and goldfish. Psychonomic Science, 1971, 22, 281-282.

Miller, J. T., Hansen, G., \& Thomas, D. R. Effect of stimulus similarity and response criterion on successive discrimination reversal learning. Journal of Comparative and Physiological Psychology, 1972, 81, 434-440.

NoRTH, A. J. Improvement in successive discrimination reversals. Journal of Comparative and Physiological Psychology, 1950, 43, 442-460.

Pubols, B. H., JR. Serial reversal learning as a function of the number of trials per reversal. Journal of Comparative and Physiological Psychology, 1962, 55, 66-68.

Rajalakshmi, R., \& JeEves, M. A. The relative difficulty of reversal learning (reversal index) as a basis of behavioural comparisons. Animal Behaviour, 1965, 13, 203-211.

SEIDman, E. Relative ability of the newt and the terrapin to reverse a direction habit. Journal of Comparative and Physiological Psychology, 1949, 42, 320-327.

Setterington, R. G., \& Bishop, H. E. Habit reversal improvement in the fish. Psychonomic Science, 1967, 7, 41-42.

Souier, L. H. Reversal learning improvement in the fish Astronotus ocellatus (oscar). Psychonomic Science, 1969, 14, 143-144.

WARREN, J. M. Reversal learning by paradish fish (Macropodus opercularis). Journal of Comparative and Physiological Psychology, 1960, 53, 376-378.

WARREN, J. M. Primate learning in comparative perspective. In A. Schrier, H. Harlow, \& F. Stollnitz (Eds.), Behavior of nonhuman primates (Vol. 1), New York: Academic Press, 1965.

W ARREN, J. M. Learning in vertebrates. In D. Dewsbury \& D. Rethlingshafer (Eds.), Comparative psychology: A modern survey. New York: McGraw-Hill, 1973.

Williams, B. A. The effects of intertrial interval on discrimination reversal learning in the pigeon. Psychonomic Science, 1971, 23, 241-243.

Williams, R. S., JR. Reversal learning in the spectacled caiman. American Journal of Psychology, 1968, 81, 258-261.

(Received for publication January $31,1979$. 